\title{
Apoptotic Effect of co-treatment with HS-1200 and Cisplatin on SCC25 Human Tongue Squamous Cell Carcinoma Cell Line
}

\author{
Duk-Han Kim, D.D.S.,M.S.D., In-Ryoung Kim, M.S.,Ph.D., \\ Bong-Soo Park, D.D.S., M.S.D., Ph.D., Yong-Woo Ahn ${ }^{1}$, D.D.S., M.S.D., Ph.D. \\ Sung-Hee Jeong ${ }^{1}$, D.M.D.,M.S.D.,Ph.D. \\ Department of Oral Anatomy, School of Dentistry, Pusan National University \\ ${ }^{1}$ Department of Oral Medicine, School of Dentistry, Pusan National University
}

Bile acids are polar derivatives of cholesterol essential for the absorption of dietary lipids and regulate the transcription of genes that control cholesterol homeostasis. Recently it have been identified the synthetic chenodeoxycholic acid (CDCA) derivatives HS-1200 and cisplatin showed apoptisis-inducing activity on various cancer cells in vivo and in

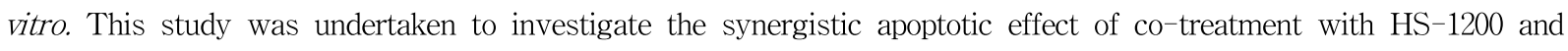
cisplatin on human tongue squamous cell carcinoma cells (SCC25 cells).

To investigate whether the co-treatment with HS-1200 and cisplatin compared to each single treatment efficiently reduces the viability of SCC25 cells, MTT assay was conducted. The induction and augmentation of apoptosis were confirmed by DNA electrophoresis, Hoechst staining and an analysis DNA hypoploidy. Westen blot analysis and immunofluorescent staining were also performed to evaluate the expression levels and the translocation of apoptosis-related proteins following this co-treatment. Furthermore, proteasome activity and mitochondrial membrane potential (MMP) change were also assayed.

In this study, co-treatment with HS-1200 and cisplatin on SCC25 cells showed several lines of apoptotic manifestation such as nuclear condensations, DNA fragmentation, reduction of MMP and proteasome activity, the increase of Bax and the decrease of $\mathrm{Bcl}-2$, decrease of DNA content, the release of cytochrome $\mathrm{c}$ into cytosol, translocation of AIF and DFF40 (CAD) onto nuclei, and activation of caspase- 9 , caspase -7 , caspase- 3 , PARP and DFF45 (ICAD) whereas each single treated SCC25 cells did not show these patterns.

Although the single treatment of $25 \mu \mathrm{M} \mathrm{HS}-1200$ and $4 \mu \mathrm{g} / \mathrm{ml}$ cisplatin for $24 \mathrm{~h}$ did not induce apoptosis, the $\mathrm{CO}^{-}$-treatment of these reagents prominently induced apoptosis. Therefore our data provide the possibility that the combination therapy with HS-1200 and cisplatin could be considered as a novel therapeutic strategy for human squamous cell carcinoma

Key words : Apoptosis, Bile acid, HS-1200, Cisplatin, Human tongue squamous carcinoma

\section{Corresponding author: Sung-Hee Jeong}

Associate Professor, Department of Oral Medicine, School of Dentistry

Beomeo-ri, Mulgeum-eup, Yangsan-si, Gyeongsangnam-do, 626-870, Korea.

Received: 2013-06-18

revised: $2013-07-29$

Accepted: 2013-08-22

*This work was supported by for two years Pusan National University research grant. 


\section{INTRODUCTION}

Cells undergoing apoptosis usually develop characteristic changes, including nuclear condensation and degradation of DNA into oligonucleosomal fragments. ${ }^{1)}$ Apoptotic cell death is thought to result ultimately from the proteolytic actions of caspase ${ }^{2)}$ and alterations in mitochondrial function play a key role in the regulation of apoptosis. ${ }^{3)}$ Moreover, the proteasome system has been shown to be implicated as a negative or positive mediator of apoptosis. The proteasome pathway is known to work mostly in upstream of mitochondrial alterations and caspase activation. ${ }^{4)}$

Carcinoma of the oral cavity, especially oral squamous cell carcinoma (OSCC), are one of the most leading causes of cancer related death and affect nearly 500,000 patients annually world-wide. And OSCC is one of the most malignancies that remain incurable with current therapies. ${ }^{5)}$ OSCC patients are treated by classical modalities of treatment consisting of surgery, radiotherapy, and/or chemotherapy. But OSCC still shows noticeable mortality rates. therefore new therapeutic approaches have been investigated and the most promising one is obtained from natural agents with known anti-cancer effects.

Bile acids are polar derivatives of cholesterol essential for the absorption of dietary lipids and regulate the transcription of genes that control cholesterol homeostasis. Different bile acids exhibit distinct biological effects. Importantly, natural bile salts were reported to inhibit cell proliferation and induce apoptosis in various cells. ${ }^{6,7)}$ Several ursodeoxycholic acid (UDCA) and chenodeoxycholic acid (CDCA) derivatives developed by Im et $\mathrm{al}^{8,9}$ and it have been reported that they had apoptosis-inducing effect in various cancer cells ${ }^{10-14)}$.

Cisplatin is one of the most potent anticancer agents showing significant clinical activity against a variety of solid tumors belonging to a class of platinum containing anti-cancer compounds. ${ }^{15)}$ It is a representative of anticancer drug used to treat certain types of head and neck cancer, cervical carcinoma, lung cancer, neurologic cancers, and a wide variety of other cancers. However, its resistance remains a significant barrier to the survival of cancer patient.

Recent studies have demonstrated that the co-treatment of an antitumor agent having the synergistic anti-cancer effect can be one of the potential therapeutic strategies reducing the extent and severity of cancer treatment-related toxicity. To date, combination treatment of HS-1200 and cisplatin has systemic account of synergistic apoptotic effects on human squamous carcinoma cell line is still scarce. Here we have investigated the synergistic apoptotic effect of co-treatment with a chenodeoxycholic acid (CDCA) derivative, HS-1200 and an anticancer drug, cisplatin on human oral squamous carcinoma (SCC25) cell line.

\section{ПI. MATERIALS AND METHODS}

\section{Reagents}

The synthetic bile acid derivative, HS-1200 was kindly provided by Professor Young-Hyun Yoo (Department of Anatomy, College of Medicine, Dong-A University, Busan, Korea). The following reagents were obtained commercially: Mouse monoclonal anti-human caspase- 3 , caspase -7 , caspase-9, poly(ADP-ribose) polymerase (PARP), cytochrome c, apoptosis-inducing factor (AIF) antibodies, and rabbit polyclonal anti-human DFF40 (CAD), DFF45 (ICAD), $\beta$-actin antibodies, and FITC-conjugated goat anti-mouse and anti-rabbit IgGs were from Santa Cruz Biotechnology (Santa Cruz, CA, USA); HRP-conjugated sheep anti-mouse and anti-rabbit IgGs were from Amersham GE Healthcare (Little Chalfront, UK). 5,5',6,6'tetrachloro-1,1',3,3'-tetraethylbenzimidazol carbocyanine iodide (JC-1) was from Molecular Probes (Eugene, OR, USA). ApoScreenTM Annexin V-FITC Apoptosis Kit was from Beckman coulter (Fullerton, CA, USA). Suc-LLVY-AMC was from Calbiochem (Darmstadt, Germany). Dulbecco's modified Eagle's medium (DMEM) and FBS were 
from Gibco (Gaithersburg, MD, USA). Dimethyl sulfoxide (DMSO), eugenol, cisplatin, Hoechst 33342, RNase A, proteinase K, aprotinin, leupeptin, PMSF, thiazolyl blue tetrazolium bromide and propidium iodide (PI) were from Sigma (St. Louis, MO, USA); SuperSignal West Pico enhanced chemiluminescence Western blotting detection reagent was from Pierce (Rockford, IL, USA).

\section{Cell culture}

The SCC25 human oral squamous carcinoma cell line was purchased from ATCC (Rockville, USA). Cells were maintained at $37^{\circ} \mathrm{C}$ with $5 \% \mathrm{CO}_{2}$ in air atmosphere in DMEM/F12 with $4 \mathrm{mM} \mathrm{L}$-glutamine, $1.5 \mathrm{~g} / 1$ sodium bicarbonate, $4.5 \mathrm{~g} / 1$ glucose and 1.0 $\mathrm{mM}$ sodium pyruvate supplemented with $10 \% \mathrm{FBS}$.

\section{Treatment of HS-1200 and cisplatin for co-treatment}

Stock solutions of HS-1200 (100 mM) and cisplatin $(25 \mathrm{mg} / \mathrm{ml})$ made by dissolving them in DMSO were kept frozen at $-20^{\circ} \mathrm{C}$ until use. Twenty four hours after SCC25 cells were subcultured, the original medium was removed. The cells were washed with PBS and then incubated in the same fresh medium. Since single treatment of $25 \mu \mathrm{M}$ HS-1200 and $4 \mu \mathrm{g} / \mathrm{ml}$ cisplatin for $24 \mathrm{~h}$ showed slight induction of cell death in MTT assay, this single concentration was utilized for further assessment of apoptosis for co-treatment. The concentration of DMSO used in this study had no effect on SCC25 cell proliferation in my preliminary studies.

\section{MTT assay}

SCC25 Cells were placed in a 96-well plate and were incubated for $24 \mathrm{~h}$. Then they were treated with $25 \mu \mathrm{M}$ HS-1200 and $4 \mu \mathrm{g} / \mathrm{ml}$ cisplatin for 24 $\mathrm{h}$ each and co-treatment with HS-1200/cisplatin were performed in the same condition for $24 \mathrm{~h}$. After cells were treated with $500 \mu \mathrm{g} / \mathrm{ml}$ of thiazolyl blue tetrazolium bromide (MTT solution), they were incubated at $37^{\circ} \mathrm{C}$ with $5 \% \mathrm{CO}_{2}$ for $4 \mathrm{~h}$. And then the medium was aspirated and formed formazan crystals were dissolved in DMSO. Cell viability was measured by an ELISA reader (Tecan, Männedorf, Switzerland) at $570 \mathrm{~nm}$ excitatory emission wavelength.

\section{Hoechst staining}

Cells were harvested and cell suspension was centrifuged onto a clean, fat-free glass slide with a cytocentrifuge. The samples were stained in $4 \mu \mathrm{g} / \mathrm{ml}$ Hoechst 33342 for $30 \mathrm{~min}$ at $37^{\circ} \mathrm{C}$ and fixed for 10 min with $4 \%$ paraformaldehyde.

\section{DNA electrophoresis}

$2 \times 10^{6}$ cells were resuspended in $1.5 \mathrm{ml}$ of lysis buffer [10 mM Tris (pH 7.5), $10 \mathrm{mM}$ EDTA (pH 8.0), $10 \mathrm{mM} \mathrm{NaCl}$ and $0.5 \%$ SDS] into which proteinase $\mathrm{K}(200 \mu \mathrm{g} / \mathrm{ml})$ was added. After samples were incubated overnight at $48^{\circ} \mathrm{C}, 200 \mu \mathrm{l}$ of ice cold $5 \mathrm{M}$ $\mathrm{NaCl}$ was added and the supernatant containing fragmented DNA was collected after centrifugation. The DNA was then precipitated overnight at $-20^{\circ} \mathrm{C}$ in 50\% isopropanol and Rnase A-treated for $1 \mathrm{~h}$ at $37^{\circ} \mathrm{C}$. The DNA from $10^{6}$ cells $(15 \mu \mathrm{l})$ was equally loaded on each lane of $2 \%$ agarose gels in Tris-acetic acid/EDTA buffer containing $0.5 \mu \mathrm{g} / \mathrm{ml}$ ethidium bromide at $50 \mathrm{~mA}$ for $1.5 \mathrm{~h}$.

\section{Proteasome activity}

Cells were collected and lysed in proteasome buffer [10 mM Tris-HCl, pH 7.5, 1 mM EDTA, 2 $\mathrm{mM}$ ATP, 20\% glycerol, and $4 \mathrm{mM}$ dithiothreitol (DTT)], sonicated, and then centrifuged at 13,000 $\mathrm{g}$ at $4^{\circ} \mathrm{C}$ for $10 \mathrm{~min}$. The supernatant (20 $\mu \mathrm{g}$ of protein) was incubated with proteasome activity buffer [0.05 $\mathrm{M}$ Tris- $\mathrm{HCl}, \mathrm{pH}$ 8.0, $0.5 \mathrm{mM}$ EDTA, $50 \mu \mathrm{M}$ Suc-LLVY-AMC] for $1 \mathrm{~h}$ at $37^{\circ} \mathrm{C}$. The fluorescence intensity of each solution was measured by a modular fluorimetric system (Spex Edison, NJ, 
USA) at $380 \mathrm{~nm}$ excitatory and $460 \mathrm{~nm}$ emission wavelengths. All readings were standardized based on the fluorescence intensity of an equal volume of free AMC solution $(50 \mu \mathrm{M})$.

\section{Western blot analysis}

Cells $\left(2 \times 10^{6}\right)$ were washed twice in ice-cold PBS, resuspended in $200 \mu \mathrm{l}$ ice-cold solubilizing buffer [300 mM NaCl, $50 \mathrm{mM}$ Tris- ${ }^{-} \mathrm{Cl}$ (pH 7.6), 0.5\% Triton X-100, $2 \mathrm{mM}$ PMSF, $2 \mathrm{\mu g} / \mathrm{ml}$ aprotinin and $2 \mathrm{\mu g} / \mathrm{ml}$ leupeptin] and incubated at $4^{\circ} \mathrm{C}$ for $30 \mathrm{~min}$. The lysates were centrifuged at 14,000 revolutions per min for 15 min at $4^{\circ} \mathrm{C}$. Protein concentrations of cell lysates were determined with Bradford protein assay (Bio-Rad, Richmond, CA, USA) and $50 \mu \mathrm{g}$ of proteins were loaded onto $7.5-15 \%$ SDS/PAGE. The gels were transferred to Nitrocellulose membrane (Amersham GE Healthcare, Little Chalfont, UK) and reacted with each antibody. Immunostaining with antibodies was performed using SuperSignal West Pico enhanced chemiluminescence substrate and detected with Alpha Imager HP (Alpha Innotech, Santa Clara, USA).

\section{Immunofluorescent staining}

Cells were cytocentrifuged and fixed for $10 \mathrm{~min}$ in $4 \%$ paraformaldehyde, incubated with each primary antibody for $1 \mathrm{~h}$, washed 3 times for $5 \mathrm{~min}$, and then incubated with FITC-conjugated secondary antibody for $1 \mathrm{~h}$ at room temperature. Cells were mounted with PBS. Fluorescent images were observed and analyzed under Zeiss LSM 700 laser-scanning confocal microscope (Göettingen, Germany).

\section{Assay of mitochondrial membrane} potential (MMP)

JC-1 was added directly to the cell culture medium (1 $\mu \mathrm{M}$ final concentration) and incubated for $15 \mathrm{~min}$. The medium was then replaced with PBS. Flow cytometry to measure MMP was performed on a CYTOMICS FC500 flow cytometry (Beckman Coulter, Brea, CA, USA). Data were acquired and analyzed using CXP software version 2.2.

\section{Quantification of DNA hypoploidy by flow cytometry}

After treatment for $24 \mathrm{~h}$, cells were harvested by trypsinization and ice cold $95 \%$ ethanol with $0.5 \%$ Tween 20 was added to the cell suspensions to a final concentration of $70 \%$ ethanol. Fixed cells were pelleted, and washed in 1\% BSA-PBS solution. Cells were resuspended in $1 \mathrm{ml}$ PBS containing $20 \mu \mathrm{g} / \mathrm{ml}$ RNase A, incubated at $4^{\circ} \mathrm{C}$ for $30 \mathrm{~min}$, washed once with BSA-PBS, and resuspended in PI solution (10 $\mu \mathrm{g} / \mathrm{ml}$ ). After cells were incubated at $4^{\circ} \mathrm{C}$ for $5 \mathrm{~min}$ in the dark, DNA content were measured on a CYTOMICS FC500 flow cytometry system (Beckman Coulter, FL, CA, USA) and data was analyzed using the Multicycle software which allowed a simultaneous estimation of cell-cycle parameters and apoptosis.

\section{RESULTS}

\section{Co-treatment with HS-1200 and cisplatin augmented the reduction in viability of SCC25 cells.}

To investigate whether the co-treatment with HS-1200 and cisplatin reduced the viability of SCC25 cells, MTT assay was conducted. Single treatment of HS-1200 at $25 \mu \mathrm{M}$ or cisplatin at $4 \mu$ $\mathrm{g} / \mathrm{ml}$ for $24 \mathrm{~h}$ reduced the viability of SCC25 cells slightly (HS-1200, 94.6\%; cisplatin, 93.4\%). Co-treatment with HS-1200 and cisplatin significantly reduced the to $45.2 \%$ cell viability vs single treatment (Fig. 1).

2. Co-treatment with HS-1200 and cisplatin augmented the nuclear condensation in SCC25 cells

To study a nuclear condensation induced by the 
co-treatment, Hoechst staining by which a hallmark of apoptosis was conducted. Hoechst staining showed a nuclear condensation by the single treatment of HS-1200 and cisplatin. Co-treatment

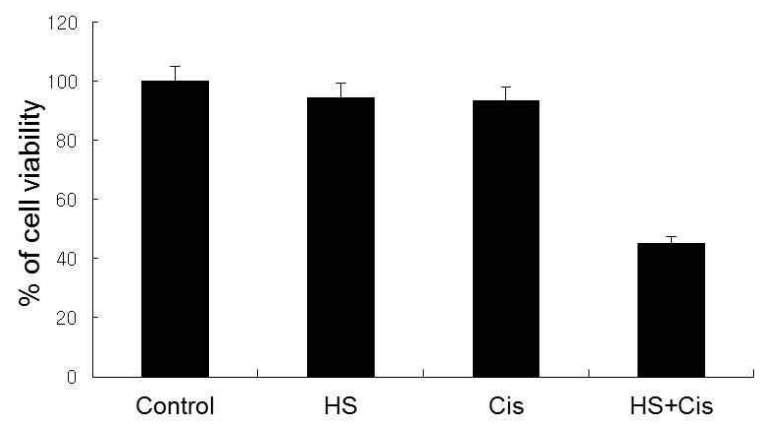

Fig. 1. Co-treatment with HS-1200 and cisplatin significantly reduced the cell viability in SCC25 cells. Cell viability was determined by MTT assay. Three independent assays were performed. Values are means \pm SD of triplicates of each experiment. (HS, cells treated with $25 \mu \mathrm{M}$ HS-1200 for $24 \mathrm{~h}$ : Cis. cells treated with $4 \mu \mathrm{g} / \mathrm{ml}$ cisplatin for $24 \mathrm{~h}$ : $\mathrm{HS}+\mathrm{Cis}$, cells treated with $25 \mu \mathrm{M} \mathrm{HS}-1200$ plus $4 \mu \mathrm{g} / \mathrm{ml}$ cisplatin for $24 \mathrm{~h}$ )

(A)
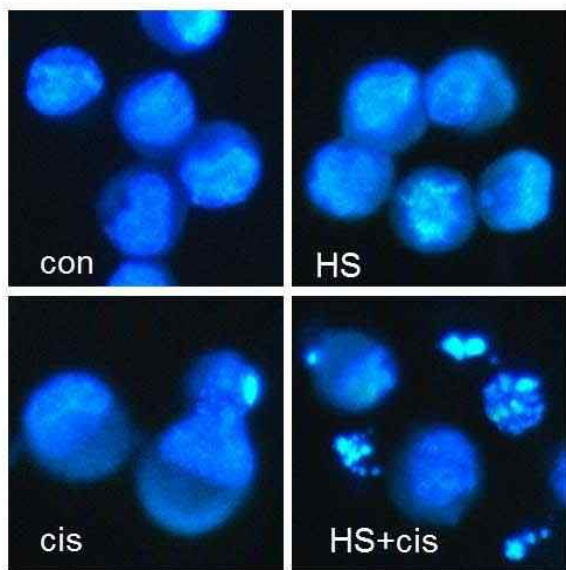

1200 and cisplatin remarkably reduced the proteasome activity, compared to the example of the single treatment (Fig. 4).

5. Augmentation of apoptosis by the $\mathrm{co}^{-}$ treatment with HS-1200 and cisplatin was demonstrated by reduction of mitochondrial membrane potential (MMP) in SCC25 cells.

Single treatment with either HS-1200 or cisplatin reduced slightly the MMP compared to control group. The co-treatment with HS-1200 and cisplatin result in the remarkable loss of MMP (Fig. 5).

6. Augmentation of apoptosis by the $\mathrm{co}^{-}$ treatment with HS-1200 and cisplatin was demonstrated by the decrease in a DNA content of SCC25 cells.

The flow cytometry result showed that the $\mathrm{co}^{-}$ treatment with HS-1200 and cisplatin significantly increased apoptotic cells with DNA hypoploidy compared to the example of single treatment (Fig. 6).

Fig. 2. Co-treatment with HS-1200 and cisplatin showed numerous condensed and fragmented nuclei in scC25 cells compared to the single treatment. (HS, cells treated with $25 \mu \mathrm{M} \mathrm{HS}-1200$ for $24 \mathrm{~h}$; cis, cells treated with $4 \mu \mathrm{g} / \mathrm{ml}$ cisplatin for $24 \mathrm{~h}$ : HS + cis, cells treated with $25 \mu \mathrm{M} \mathrm{HS}-1200$ plus $4 \mu \mathrm{g} / \mathrm{ml}$ cisplatin for 24 h) (A) Immunofluorescent micrographs showing nuclear morphology after Hoechst staining. (B) The values below micrographs are represented as the mean \pm SD of the means of apoptotic cells as determined by Hoechst staining. The results presented are representative of three independent experiments. 


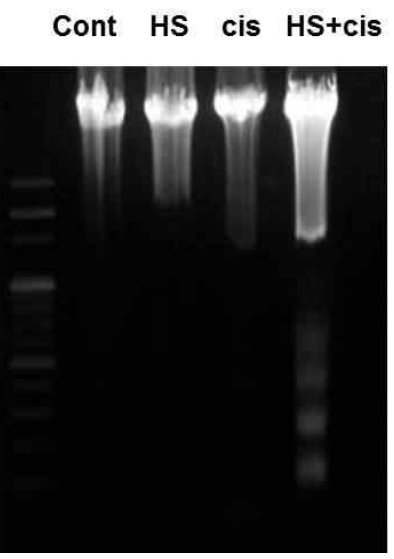

Fig. 3. Co-treatment with HS-1200 and cisplatin efficiently showed DNA fragmentation in SCC25 cells. DNA fragmentation analysis was determined by the agarose gel electrophoresis. Whereas single treated cells showed no DNA fragmentation, co-treated cells showed DNA degradation characteristic of apoptosis with a ladder pattern of DNA fragments. (HS, cells treated with $25 \mu \mathrm{M} \mathrm{HS}-1200$ for $24 \mathrm{~h}$; cis, cells treated with $4 \mu \mathrm{g} / \mathrm{ml}$ cisplatin for $24 \mathrm{~h}$; $\mathrm{HS}+$ cis, cells treated with $25 \mu \mathrm{M} \mathrm{HS}-1200$ plus $4 \mu \mathrm{g} / \mathrm{ml}$ cisplatin for $24 \mathrm{~h}$ )

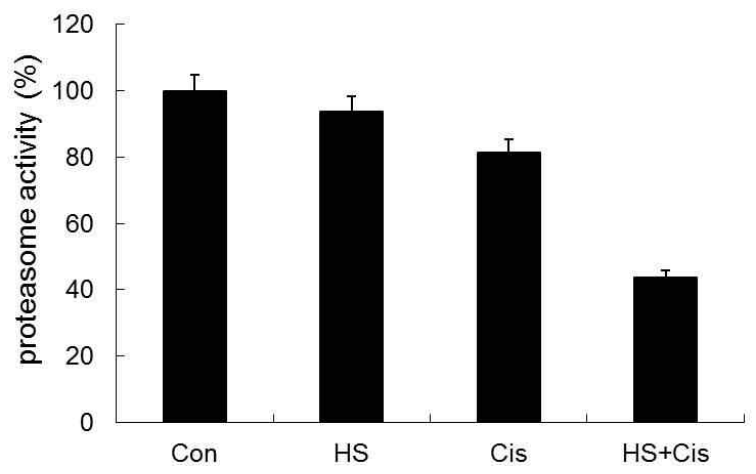

Fig. 4. Co-treatment with HS-1200 and cisplatin significantly showed the reduction of proteasome activity in SCC25 cells compared to the single treatment. Three independent assays were performed. Values are means \pm SD of triplicates of each experiment. (HS, cells treated with 25 $\mu \mathrm{M} \mathrm{HS}-1200$ for $24 \mathrm{~h}$; cis, cells treated with $4 \mathrm{\mu g} / \mathrm{ml}$ cisplatin for $24 \mathrm{~h}$; HS + cis, cells treated with $25 \mu \mathrm{M}$ HS-1200 plus $4 \mu \mathrm{g} / \mathrm{ml}$ cisplatin for $24 \mathrm{~h}$ )
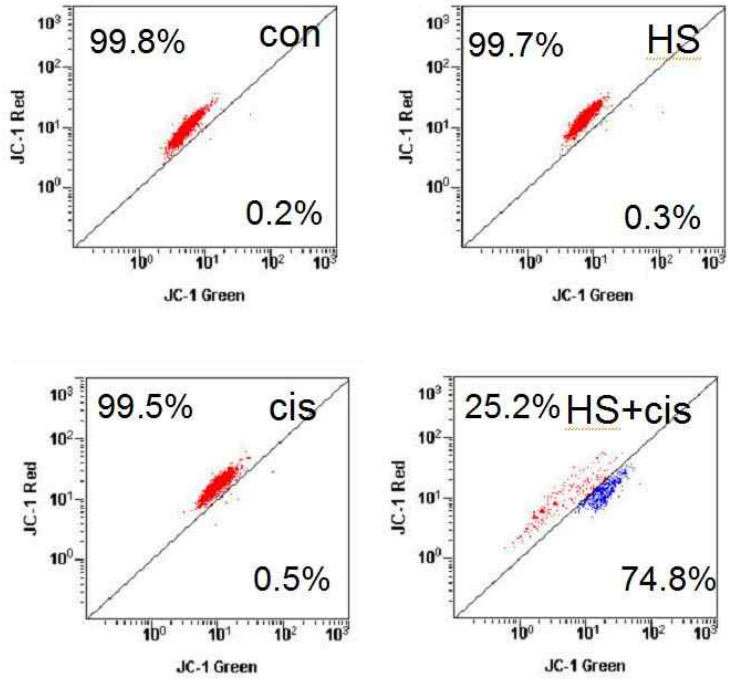

Fig. 5. Co-treatment with HS-1200 and cisplatin showed remarkably the loss of MMP ( $\triangle \psi m)$ compared to the single treatmemt. MMP was measured by $\mathrm{JC}^{-1}$ with flow cytometry. (HS, cells treated with $25 \mu \mathrm{M} \mathrm{HS}-1200$ for $24 \mathrm{~h}$; cis, cells treated with $4 \mathrm{\mu g} / \mathrm{ml}$ cisplatin for $24 \mathrm{~h}$ : HS+cis, cells treated with $25 \mu \mathrm{M} \mathrm{HS}-1200$ plus $4 \mu \mathrm{g} / \mathrm{ml}$ cisplatin for $24 \mathrm{~h}$ )

7. Co-treatment with HS-1200 and cisplatin caused the translocation of AIF from mitochondria onto the nucleus.

The confocal microscopy showed that AIF was located at mitochondria in the single treatment of HS-1200 or cisplatin whereas AIF was evidently translocated onto nuclei in the co-treatment (Fig. 7).

8. Co-treatment with HS-1200 and cisplatin caused the release of cytochrome $\mathrm{c}$ from mitochondria into the cytosol.

The confocal microscopy showed that cytochrome c was located at mitochondria in the single treatment with either HS-1200 or cisplatin whereas cytochrome c was evidently released into the cytosol by the $\mathrm{co}^{- \text {treatment (Fig. 8). }}$ 

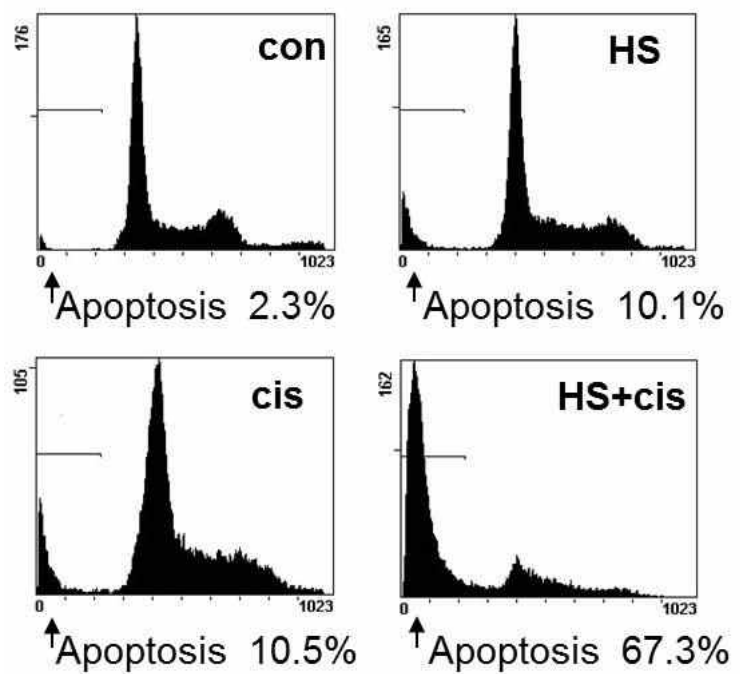

Fig. 6. The kinetic analysis of the effect of $\mathrm{co}^{-}$ treatment on the SCC25 cell cycle progression and the induction of apoptosis. Co-treatment showed remarkable increase of apoptotic cells with DNA hypoploidy compared to the single treatment. (HS, cells treated with $25 \mu \mathrm{M} \mathrm{HS}-1200$ for $24 \mathrm{~h}$; cis, cells treated with $4 \mu \mathrm{g} / \mathrm{ml}$ cisplatin for $24 \mathrm{~h}$ : HS+cis, cells treated with $25 \mu \mathrm{M}$ HS-1200 plus $4 \mu \mathrm{g} / \mathrm{ml}$ cisplatin for $24 \mathrm{~h}$

9. Augmentation of apoptosis by $\mathrm{co}^{-}$ treatment with HS-1200 and cisplatin was demonstrated by Western blot assay.

The expression level of anti-apoptotic protein, Bcl-2 decreased and the expression level of apoptotic protein, Bax increased by the co-treatment (Fig. 9). The co-treatment with HS-1200 and cisplatin induced the degradation of caspase -9 , caspase -3 , caspase -7 and PARP, and produced the processed DFF45 (ICAD) $11 \mathrm{kDa}$, PARP $85 \mathrm{kDa}$ and

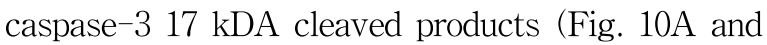
Fig. 11).
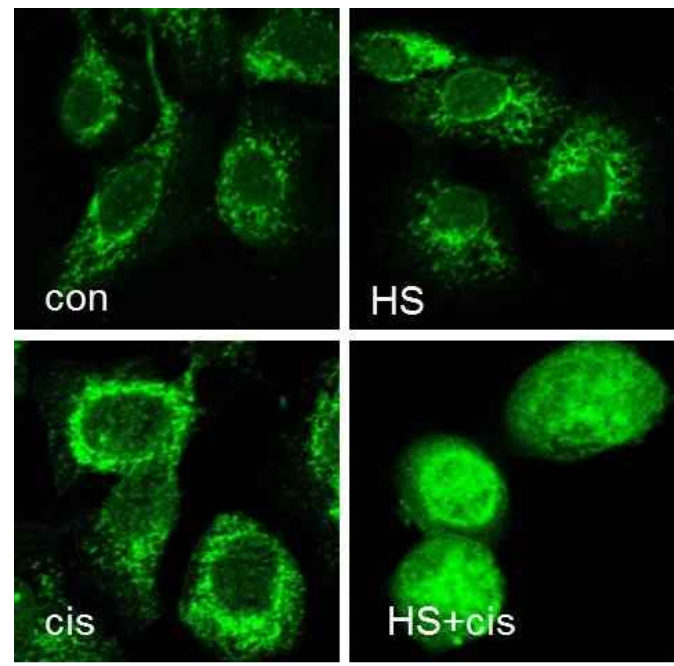

Fig. 7. The confocal microscopy showed that AIF was evidently translocated onto nuclei in SCC25 cells when co-treated with HS-1200 and cisplatin. (HS, cells treated with $25 \mu \mathrm{M}$ HS-1200 for $24 \mathrm{~h}$ : cis, cells treated with 4 $\mu \mathrm{g} / \mathrm{ml}$ cisplatin for $24 \mathrm{~h}$; HS + cis, cells treated with $25 \mu \mathrm{M} \mathrm{HS}-1200$ plus $4 \mu \mathrm{g} / \mathrm{ml}$ cisplatin for $24 \mathrm{~h}$ )
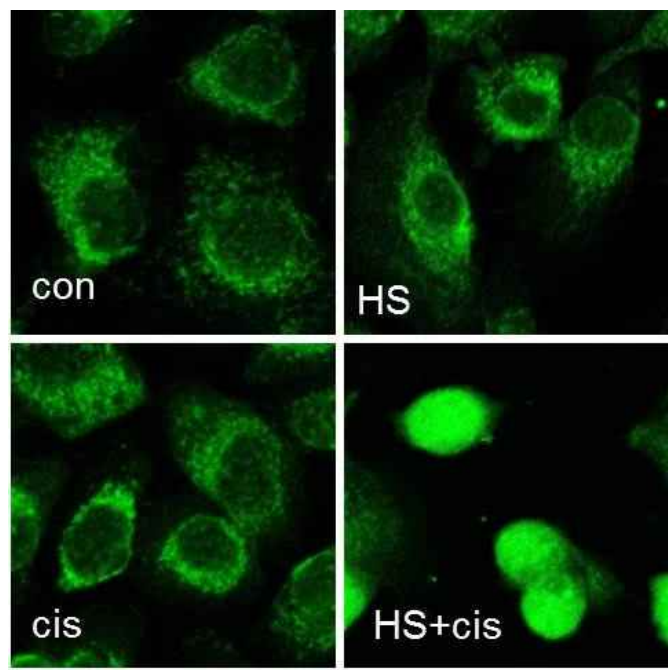

Fig. 8. The confocal microscopy showed that cytochrome c was evidently released to the cytosol in SCC25 cells that were co-treated with HS-1200 and cisplatin. (HS, cells treated with $25 \mu \mathrm{M} \mathrm{HS}-1200$ for $24 \mathrm{~h}$; cis, cells treated with $4 \mu \mathrm{g} / \mathrm{ml}$ cisplatin for $24 \mathrm{~h}$; $\mathrm{HS}+$ cis, cells treated with $25 \mu \mathrm{M} \mathrm{HS}-1200$ plus $4 \mu \mathrm{g} / \mathrm{ml}$ cisplatin for $24 \mathrm{~h}$ ) 


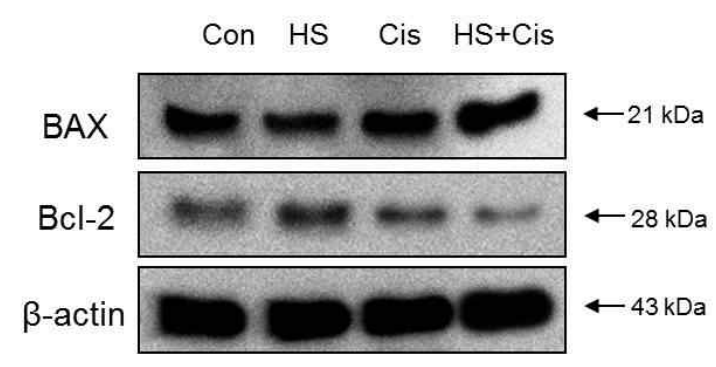

Fig 9. Western blot analysis showing that $\mathrm{co}^{-}$ treatment with HS-1200 and cisplatin induced up-regulation of the Bax and down-regulation of the $\mathrm{Bcl}-2$. The levels of $\beta$-actin were used as an internal standard for quantifying $\mathrm{Bcl}-2$ and Bax expression. (HS, cells treated with $25 \mu \mathrm{M}$ HS-1200 for $24 \mathrm{~h}$; cis, cells treated with $4 \mu \mathrm{g} / \mathrm{ml}$ cisplatin for $24 \mathrm{~h}$; HS+cis, cells treated with $25 \mu \mathrm{M} \mathrm{HS}-1200$ plus $4 \mu \mathrm{g} / \mathrm{ml}$ cisplatin for $24 \mathrm{~h}$ )

(A) Con $\mathrm{HS}$ Cis $\mathrm{HS}+\mathrm{Cis}$

DFF45 (ICAD)

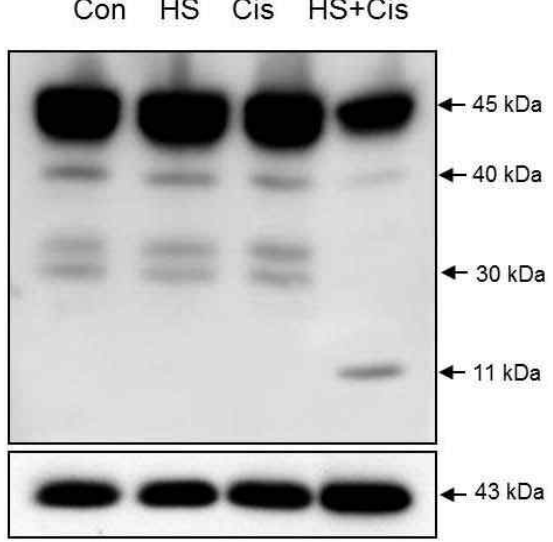

10. Co-treatment with HS-1200 and cisplatin caused the translocation of DFF40 (CAD) from cytosol onto the nuclei.

The confocal microscopy showed that DFF40 (CAD) was located at cytosol by the single treatment with either HS-1200 or cisplatin whereas DFF40 (CAD) was evidently translocated into the nuclei by the $\mathrm{co}^{-}$treatment (Fig. 10B).

\section{DISCUSSION}

Bile acids are steroid acids that is produced in mammalians liver and stored in the gall bladder. The function of bile acid is to facilitate the formation of micelles, which promotes processing of dietary fat. Several reports demonstrated that natural bile salts, ursodeoxycholic acid (UDCA) and chenodeoxycholic acid (CDCA) were inhibit cell proliferation and induce apoptosis in various cells. ${ }^{10-14)}$ Also, it has been reported that the synthetic CDCA derivatives

(B)
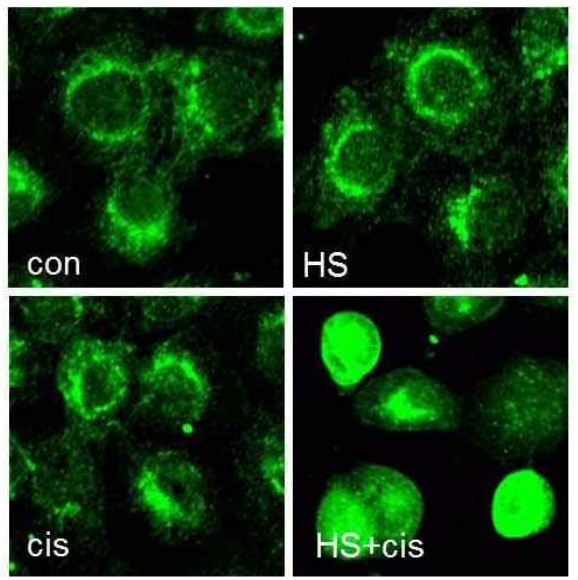

Fig. 10. Western blot analysis and confocal microscopy showing the efficient apoptotic effects in SCC25 cells co-treated with HS-1200 and cisplatin. (HS, cells treated with $25 \mu \mathrm{M} \mathrm{HS}-1200$ for $24 \mathrm{~h}$; cis, cells treated with $4 \mu \mathrm{g} / \mathrm{ml}$ cisplatin for $24 \mathrm{~h}$ : HS + cis, cells treated with $25 \mu \mathrm{M} \mathrm{HS}-1200$ plus $4 \mu \mathrm{g} / \mathrm{ml}$ cisplatin for $24 \mathrm{~h}$ ) (A) The co-treatment remarkably induced DFF45 (ICAD) degradation and produced the processed DFF45 $11 \mathrm{kDa}$ cleaved product. B-actin, a loading control. (B) The confocal microscopy showed that DFF40 (CAD) was translocated onto the nuclei in the co-treatment of HS-1200 and cisplatin. 


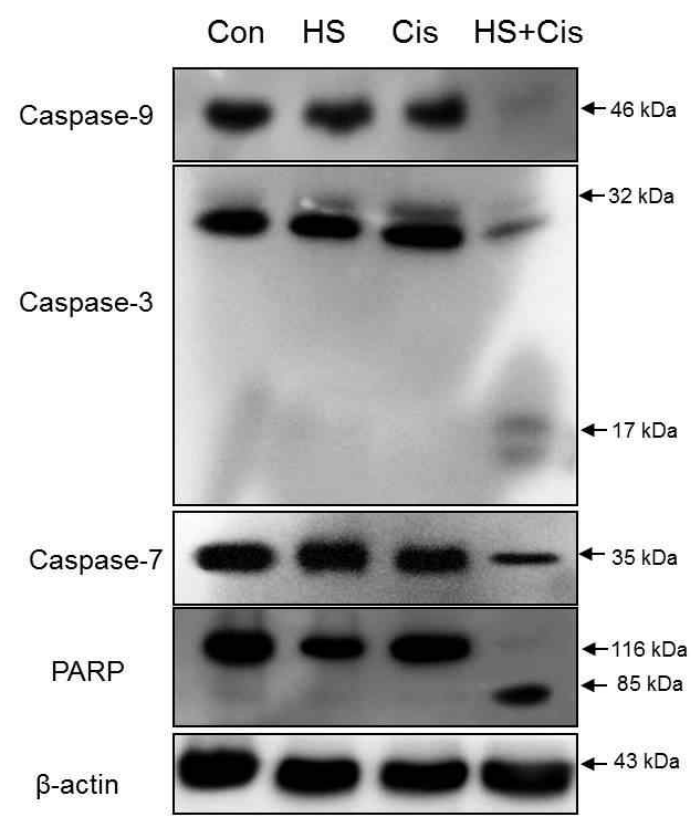

Fig. 11. Western blot analysis showing that the cotreatment with HS-1200 and cisplatin in SCC25 cells remarkably induced Caspase9. Caspase-3, Caspase-7 and PARP degradations and produced the processed Caspase-3 $17 \mathrm{kDa}$, and PARP $85 \mathrm{kDa}$ cleaved products. $\beta$-actin, a loading control. (HS, cells treated with $25 \mu \mathrm{M}$ HS-1200 for $24 \mathrm{~h}$; cis, cells treated with 4 $\mu \mathrm{g} / \mathrm{ml}$ cisplatin for $24 \mathrm{~h}$; HS + cis, cells treated with $25 \mu \mathrm{M} \mathrm{HS}-1200$ plus $4 \mu \mathrm{g} / \mathrm{ml}$ cisplatin for $24 \mathrm{~h}$ )

induce the antiproliferative efficacy in various cancer cells by inducing apoptosis. Those studies demonstrated the decrease of proteasome activity, mitochondrial events, and nuclear condensation ${ }^{16-18}$ in synthetic CDCA derivatives-induced apoptosis. In addition, it has been demonstrated that a synthetic CDCA derivative, HS-1200 shows the strongest apoptosis-inducing effect among the synthetic CDCA derivatives. ${ }^{11,14,18)}$

Since from the 1970s, the neutral, square planar, coordination complex cis-diamminedichloroplatinum (II) (cisplatin) has become more and more popular in the treatment of cancer. Cisplatin, which is a well-known DNA-damaging agent and one of the most active cancer treatment agents available, is widely used for the treatment of many malignancies, including testicular, ovarian, bladder, cervical, head and neck, and small-cell and non-small-cell lung cancers. Unfortunately, however, cisplatin causes many untoward side effects. ${ }^{19,20)}$ It have been reported that cisplatin-induced cell death is involved in apoptotic ${ }^{-}$and cell cycle-regulating pathways. 21-27) Moreover, the synergistic antitumor effect of the combination treatment with cisplatin and antitumor agents or natural products have also been demonstrated. ${ }^{28-31)}$

If the co-treatment with a synthetic CDCA derivative, HS-1200 and a representative of anticancer drug, cisplatin which has severe toxicity and resistance in the chemotherapy, shows a synergistic antitumor effect, it could be a more fundamental therapeutic strategy for cancer chemotherapy.

Proteasome is a fundamental non-lysosomal tool that cells use to process or degrade a variety of short-living proteins. It was reported that proteolysis mediated by ubiquitin-proteasome system has been reported to be implicated in the regulation of apoptosis. ${ }^{32}$ The proteasome pathway is mostly known to work at the upstream of the mitochondrial alterations and caspase activation. ${ }^{4)}$ In this study, the co-treatment with HS-1200 and cisplatin on SCC25 cells causes the significant reduction of proteasome acitivity compared to the single treatment.

Mitochondria plays an important role in the induction of the mitochondrial permeability transition and also plays a key part in the regulation of apoptosis. ${ }^{3,33,34)}$ Outer mitochondrial membrane becomes permeable to intermembrane space proteins such as cytochrome c and AIF (apoptosis inducing factor) during apoptosis. ${ }^{35)}$ Release of cytochrome c and disruption of mitochondrial membrane potential (MMP) are known as features in apoptosis triggered by proteasome inhibition. ${ }^{36,37)}$ On induction of apoptosis, AIF translocates to the nucleus, resulting in chromatin condensation and large- ${ }^{-}$scale DNA fragmentation. ${ }^{38)}$ This study evidently showed that 
co-treatment with HS-1200 and cisplatin on SCC25 cells results in remarkable decrease of MMP, increase and decrease of Bax and $\mathrm{Bcl}-2$, the release of cytochrome $\mathrm{c}$ into cytosol and translocation of AIF onto nuclei whereas the single treatment does not show these patterns.

A common final event of apoptosis is the nuclear condensation, which is controlled by caspases, DFF, and PARP. Caspases play an essential role during apoptotic death. ${ }^{39)}$ Once activated, the effector caspases (caspase -3 , caspase -6 or caspase-7) are responsible for the proteolytic cleavage of a broad spectrum of cellular targets, ultimately leading to cell death. The known cellular substrates include structural components (such as actin and nuclear lamin), inhibitors of deoxyribonuclease (such as DFF45 or ICAD) and DNA repair proteins. (such as PARP) ${ }^{40,41)}$ In apoptotic cells, activation of DFF40 (CAD), also a substrate of caspase- 3 , occurs with the cleavage of DFF45 (ICAD). Once DFF40 is activated and released from the complex of DFF45 and DFF40, it can translocate to the nucleus and then degrade chromosomal DNA and produce DNA fragmentation. ${ }^{42)}$ This study demonstrated that co-treatment with HS-1200 and cisplatin in SCC25 cells results in the degradation and the cleavage of caspase -9 , caspase -3 , caspase -7 , PARP and DFF45 (ICAD), and also the translocation of DFF40 (CAD) onto nuclei whereas the single treatment does not.

Taken collectively, combination therapy with HS-1200 and cisplatin could be considered, in the future, as an alternative therapeutic strategy for human oral squamous carcinoma. Its clinical application awaits further extensive studies.

\section{REFERENCES}

1. Williams GT. Programmed cell death: apoptosis and oncogenesis. Cell 1991;65:1097-1098.

2. Yuan J. Evolutionary conservation of a genetic pathway of programmed cell death. J Cell Biochem 1996;60:4-11.

3. Susin SA, Lorenzo HK, Zamzami N et al. Molecular characterization of mitochondrial apoptosis-inducing factor. Nature 1999;397:441-446.
4. Orlowski RZ. The role of the ubiquitin-proteasome pathway in apoptosis. Cell Death Differ 1999;6: 303-313.

5. Shen J, Huang C, Jiang $\mathrm{L}$ et al. Enhancement of cisplatin induced apoptosis by suberoylanilide hydroxamic acid in human oral squamous cell carcinoma cell lines. Biochem Pharmacol 2007;73: 1901-1909.

6. Jones B, Roberts PJ, Faubion WA, Kominami E, Gores GJ. Cystatin A expression reduces bile salt-induced apoptosis in a rat hepatoma cell line. Am J Physiol 1998;275:G723-730

7. Martinez JD, Stratagoules ED, LaRue JM et al. Different bile acids exhibit distinct biological effects: the tumor promoter deoxycholic acid induces apoptosis and the chemopreventive agent ursodeoxycholic acid inhibits cell proliferation. Nutr Cancer 1998;31:111-118.

8. Im EO, Choi YH, Paik KJ et al. Novel bile acid derivatives induce apoptosis via a p53-independent pathway in human breast carcinoma cells. Cancer Lett 2001;163:83-93

9. Im EO, Lee S, Suh H, Kim KW, Bae YT, Kim ND. A novel ursodeoxycholic acid derivative induces apoptosis in human MCF-7 breast cancer cells. Pharm Pharmacol Commun 1999;5:293-298.

10. Jeong JH, Park JS, Moon B et al. Orphan nuclear receptor Nur77 translocates to mitochondria in the early phase of apoptosis induced by synthetic chenodeoxycholic acid derivatives in human stomach cancer cell line SNU-1. Ann N Y Acad Sci 2003;1010:171-177.

11. Seo SY, Jun EJ, Jung SM et al. Synthetic chenodeoxycholic acid derivative HS-1200-induced apoptosis of p815 mastocytoma cells is augmented by co-treatment with lactacystin. Anticancer Drugs 2003;14:219-225.

12. Park SE, Choi HJ, Yee SB et al. Synthetic bile acid derivatives inhibit cell proliferation and induce apoptosis in HT-29 human colon cancer cells. Int J Oncol 2004;25:231-236.

13. Im E, Choi SH, Suh $\mathrm{H}$ et al. Synthetic bile acid derivatives induce apoptosis through a c-Jun $\mathrm{N}$-terminal kinase and $\mathrm{NF}$-kappaB-dependent process in human cervical carcinoma cells. Cancer Lett 2005;229:49-57.

14. Kim ND, Im E, Yoo YH, Choi YH. Modulation of the cell cycle and induction of apoptosis in human cancer cells by synthetic bile acids. Curr Cancer Drug 
Targets 2006;6:681-689.

15. Wang G, Reed E, Li QQ. Molecular basis of cellular response to cisplatin chemotherapy in non-small cell lung cancer (Review). Oncol Rep 2004;12: 955-965.

16. Choi YH, Im EO, Suh $\mathrm{H}$ et al. Apoptotic activity of novel bile acid derivatives in human leukemic $\mathrm{T}$ cells through the activation of caspases. Int $\mathrm{J}$ Oncol 2001;18:979-984.

17. Yoon HS, Rho JH, Yoo KW et al. Synthetic bile acid derivatives induce nonapoptotic death of human retinal pigment epithelial cells. Curr Eye Res 2001;22: 367-374.

18. Choi YH, Im EO, Suh $\mathrm{H}$ et al. Apoptosis and modulation of cell cycle control by synthetic derivatives of ursodeoxycholic acid and chenodeoxycholic acid in human prostate cancer cells. Cancer Lett 2003;199:157-167.

19. Cooley ME, Davis LE, DeStefano MAbrahm J. Cisplatin: a clinical review. Part I--Current uses of cisplatin and administration guidelines. Cancer Nurs 1994;17:173-184.

20. Gonzalez VM, Fuertes MA, Alonso C, Perez JM. Is cisplatin-induced cell death always produced by apoptosis? Mol Pharmacol 2001;59:657-663.

21. Seki K, Yoshikawa H, Shiiki K et al. Cisplatin (CDDP) specifically induces apoptosis via sequential activation of caspase $-8,-3$ and -6 in osteosarcoma. Cancer Chemother Pharmacol 2000;45:199-206.

22. Del Bello B, Valentini MA, Comporti M, Maellaro E. Cisplatin-induced apoptosis in melanoma cells: role of caspase- 3 and caspase -7 in Apaf-1 proteolytic cleavage and in execution of the degradative phases. Ann N Y Acad Sci 2003;1010:200-204.

23. Zhou H, Kato A, Yasuda $\mathrm{H}$ et al. The induction of cell cycle regulatory and DNA repair proteins in cisplatin-induced acute renal failure. Toxicol Appl Pharmacol 2004;200:111-120.

24. Fox SA, Kusmiaty, Loh SS, Dharmarajan AM, Garlepp MJ. Cisplatin and TNF-alpha downregulate transcription of $\mathrm{Bcl}-\mathrm{xL}$ in murine malignant mesothelioma cells. Biochem Biophys Res Commun 2005;337:983-991.

25. Yde CW, Issinger OG. Enhancing cisplatin sensitivity in $\mathrm{MCF}-7$ human breast cancer cells by down-regulation of $\mathrm{Bcl}-2$ and cyclin D1. Int J Oncol 2006;29:1397-1404.

26. Garcia-Berrocal JR, Nevado J, Ramirez-Camacho R et al. The anticancer drug cisplatin induces an intrinsic apoptotic pathway inside the inner ear. $\mathrm{Br} \mathrm{J}$
Pharmacol 2007;152:1012-1020

27. Gagnon V, Van Themsche C, Turner S, Leblanc V, Asselin E. Akt and XIAP regulate the sensitivity of human uterine cancer cells to cisplatin, doxorubicin and taxol. Apoptosis 2008;13:259-271.

28. Kondo K, Yamasaki S, Inoue N et al. Prospective antitumor effects of the combination of tumor necrosis factor-related apoptosis-inducing ligand (TRAIL) and cisplatin against esophageal squamous cell carcinoma. Surg Today 2006;36:966-974.

29. Mohammad RM, Banerjee S, Li $\mathrm{Y}$ et al. Cisplatin-induced antitumor activity is potentiated by the soy isoflavone genistein in $\mathrm{BxPC}-3$ pancreatic tumor xenografts. Cancer 2006;106:1260-1268.

30. Iwase M, Yoshiba S, Uchid M et al. Enhanced susceptibility to apoptosis of oral squamous cell carcinoma cells subjected to combined treatment with anticancer drugs and phosphatidylinositol 3-kinase inhibitors. Int J Oncol 2007;31:1141-1147.

31. Pisano C, Vesci L, Fodera R et al. Antitumor activity of the combination of synthetic retinoid ST1926 and cisplatin in ovarian carcinoma models. Ann Oncol 2007;18:1500-1505.

32. Drexler HC, Risau W, Konerding MA. Inhibition of proteasome function induces programmed cell death in proliferating endothelial cells. FASEB J 2000;14: 65-77.

33. Kroemer G. Mitochondrial control of apoptosis: an introduction. Biochem Biophys Res Commun 2003; 304:433-435.

34. Green DR, Reed JC. Mitochondria and apoptosis. Science 1998;281:1309-1312.

35. Golab J, Stoklosa T, Czajka A et al. Synergistic antitumor effects of a selective proteasome inhibitor and TNF in mice. Anticancer Res 2000;20:1717- 1721.

36. Wagenknecht B, Hermisson M, Groscurth $\mathrm{P}$ et al. Proteasome inhibitor-induced apoptosis of glioma cells involves the processing of multiple caspases and cytochrome c release. J Neurochem 2000;75:22882297.

37. Marshansky V, Wang $\mathrm{X}$, Bertrand $\mathrm{R}$ et al. Proteasomes modulate balance among proapoptotic and antiapoptotic $\mathrm{Bcl}-2$ family members and compromise functioning of the electron transport chain in leukemic cells. J Immunol 2001;166:31303142.

38. Daugas E, Nochy D, Ravagnan L et al. Apoptosisinducing factor (AIF): a ubiquitous mitochondrial oxidoreductase involved in apoptosis. FEBS Lett 
2000;476:118-123.

39. Acehan D, Jiang X, Morgan DG et al. Threedimensional structure of the apoptosome: implications for assembly, procaspase- 9 binding, and activation. Mol Cell 2002;9:423-432

40. Gross A, McDonnell JM, Korsmeyer SJ. BCL-2 family members and the mitochondria in apoptosis. Genes Dev 1999;13:1899-1911.
41. Porter AG. Protein translocation in apoptosis. Trends Cell Biol 1999;9:394-401.

42. Cheng AC, Jian $\mathrm{CB}$, Huang YT et al. Induction of apoptosis by Uncaria tomentosa through reactive oxygen species production, cytochrome c release, and caspases activation in human leukemia cells. Food Chem Toxicol 2007;45:2206-2218. 


\title{
국문초록
}

\section{HS-1200과 cisplatin의 병용처리가 사람구강암세포에 미치는 세포자멸사 효과에 대한 연구}

\author{
김덕한 · 김인령 · 박봉수 · 안용우 ${ }^{1}$ 정성희 ${ }^{1}$ \\ 부산대학교 치의학전문대학원 구강해부학교실, ${ }^{1}$ 부산대학교 치의학전문대학원 구강내과학교실
}

담즙산은 지방의 흡수와 콜레스테롤의 항상성을 조절하는 유전자의 전사에 관여하는 필수 콜레스테롤의 생성물이다. 담즙 산 합성유도체인 HS-1200이 여러 가지 암세포에서 세포자멸사(apoptosis)를 유도한다는 것이 알려져 있다. 본 연구는 사람혀 편평세포암종세포(SCC25 cells)에서 담즙산 합성유도체인 HS-1200과 대표적인 항암제인 cisplatin의 병용처리 후 세포자멸 사 증가효과가 있는지 알아보기 위해 수행하였다.

HS-1200과 cisplatin의 병용처리가 단독처리에 비해서 효과적인 세포생존율 감소가 있는지 확인하기 위해서 MTT법을 시 행하였고, 세포자멸사의 유도와 증가를 알기 위해서는 DNA 전기영동법, Hoechst 염색법, DNA hypoploidy법 을 사용하였다. 그리고 세포자멸사에 관계하는 단백질의 발현 변화와 세포내에서의 이동을 밝혀내기 위해서 Western blot 분석과 면역형광 염색법을 수행하였다. 더 나아가서 proteasome 활성도와 사립체막 전위 변화를 측정하였다.

본 연구에서는 HS-1200과 cisplatin을 병용처리한 SCC25 세포에서 핵의 농축, DNA분절, MMP와 proteasome 활성도의 감 소, $\mathrm{Bax}$ 의 증가와 $\mathrm{Bcl}-2$ 의 감소, $\mathrm{DNA}$ 양의 감소, cytochrome c의 세포질로의 유리, $\mathrm{AIF}$ 와 $\mathrm{DFF} 40(\mathrm{CAD})$ 의 핵으로의 이동, caspase-9, caspase-7, caspase-3, PARP 그리고 DFF45(ICAD)의 활성화와 같은 다양한 세포자멸사 증거를 보였다. 반면에 상기 물질들에 단독처리 된 $\mathrm{SCC} 25$ 세포에서는 세포자멸사 현상이 거의 없었다.

24 시간 동안 $25 \mu \mathrm{M}$ 의 HS- $1200,4 \mu \mathrm{g} / \mathrm{ml}$ 의 cisplatin 을 각기 단독처리 한 결과에서는 세포자멸사를 거의 유도하지 못했으나, 병용처리한 결과에는 아주 탁월하고 명확한 세포자멸사의 유도를 보였다. 그러므로 본 실험결과는 HS-1200과 cisplatin 의 병용요법이 사람구강편평세포암종 환자를 위해 새로운 치료전략으로서의 가능성을 보여준다고 생각한다.

Key words: 세포자멸사, 담즙산, HS-1200, cisplatin, 사람혀편평상피암종 